\title{
Pattern of Medicine Prescribing in PHC Facilities before and after earthquake in Nepal
}

\section{Gajendra Bahadur Bhuju',2, Kumud Kumar Kafle ${ }^{1,3}$, Radha Raman Prasad, ${ }^{1,4}$, Vabha Rajbhandari, ${ }^{1,5}$, Gorkha Bahadur DC ${ }^{1,6}$, Shiba Bahadur Karkee ${ }^{1,2}$, Bimal Man Shrestha ${ }^{1,7}$ and Praful Pradhananga, ${ }^{1,8}$}

${ }^{1}$ Pharmaceutical Horizon of Nepal

${ }^{2}$ Centre Institute of Science and Technology, New Baneshwor, Kathmandu, Nepal

${ }^{3}$ College of Medicine, Nepalese Army Institute of Health Sciences, Syanobharyang,Kathmandu, Nepal

${ }^{4}$ Association of Pharmaceutical Producers of Nepal, Nepal

${ }^{5}$ Sun Pharmaceuticals Limited

${ }^{6}$ Nepal Ausadhi Limited, Babarmahal, Kathmandu, Nepal

${ }^{7}$ Canadian Diabetes Association

${ }^{8}$ Agrata Health Education and Development (AHEAD)-Nepal, Kathmandu, Nepal

\begin{abstract}
Introduction: On April and May 2015, Nepal experienced two earthquakes. Many studies have focused on acute care delivery, disease outbreaks, mental health issues, and disaster relief post-earthquakes. Few others have looked at psychiatric medication prescription and health aid distribution pattern, only one study has addressed the effects of an earthquake on medication prescribing patterns and compared them to the post earthquake setting. This paper aims to examine common health problems and prescribing practices before and after the earthquake.

Methods: This descriptive retrospective study was conducted within seven randomly selected health posts (HPs) located in the three most earthquake-affected districts of Bhaktapur, Kathmandu and Dhading. The patient records per month from each HP were selected from the out patient department (OPD) register by systematic random sampling for three months prior and three months after the earthquake. There were 584 and 654 encounters in the pre and post earthquake period respectively. Each patient record was analysed using WHO drug use indicators and national treatment guidelines.

Results: A significant decrease in encounters receiving antibiotics and cases receiving albendazole alone in worm infestation was found in the post-earthquake period. A significant increase in prescribing antibiotics in cases of common cold was found.

Conclusions: The common health problems were similar in both periods. However, prescribing practices were changed. As prescriptions related to mental health problems were lacking, there is a need for improving mental health education to the health workers.

Key words: Health post; Health problem; National treatment guidelines; WHO drug use indicators
\end{abstract}

Correspondence: Gajendra Bahadur Bhuju, Centre Institute of Science and Technology, New Baneshwor, Kathmandu, Nepal. Email: gbhuju@yahoo.com

DOI: $10.3126 / \mathrm{mj}$ sbh.v20i1.28552

Submitted on: $2020-04-22$

Accepted on: 2021-01-9 


\section{INTRODUCTION}

On April 25, 2015 and May 12, 2015, Nepal, a lowincome country, experienced two earthquakes measuring 7.8 $\mathrm{M}_{\mathrm{w}}$ and 7.3 $\mathrm{M}_{\mathrm{w}}$ on the Richter scale respectively. ${ }^{1}$ These earthquakes followed by multiple after shocks killed over 8700 people, injured over 22,000, and resulted in an economic loss of US\$5-10 billion. $^{2-4}$ A total of 1100 health facilities were damaged and the most affected districts were Kathmandu, Sindhupalchowk, Lalitpur, Bhaktapur, Nuwakot, and Dhading. ${ }^{2}$ Postearthquake effects, population displacement, overcrowding, and poor sanitation led to concerns regarding the risks of infectious diseases and their widespread transmission. ${ }^{5,6}$ However, the Epidemiology and Disease Control Division (EDCD) within the Ministry of Health and Population (MoHP) in collaboration with the Chinese medical team undertook disease surveillance and rapid preventative and control measures until the end of May 2015, thus minimising outbreaks. ${ }^{7}$ Such measures dampen the long-term health effects of natural disasters and therefore lead to a reduction in the utilisation of antibiotics. Nepal is not new to earthquakes. The Himalayan nation was hit by a massive $8.1 \mathrm{M}_{\mathrm{w}}$ earthquake in 1934, and its position over three major tectonic zones renders it susceptible to future earthquakes. ${ }^{8}$

Many studies have focused on acute care delivery, disease outbreaks, mental health issues, and disaster relief post-earthquakes. ${ }^{9-12}$ Few others have looked at psychiatric medication prescription and health aid distribution pattern following an earthquake. ${ }^{13-15}$ However, few studies have addressed the effects of an earthquake on medication prescribing patterns and compared them to the post earthquake setting. ${ }^{16,17}$ Analysing the prescription pattern and medication utilisation following a disaster may help to identify gaps in prescribing and health education while also highlighting region-specific diseases and treatment to better equip national healthcare providers and international medical relief teams for future events. Department of Health Services (DoHS) is responsible for delivering preventive, promotive,diagnostic and curative health services throughout Nepal. The recently restructured DoHS has five divisions. The seven provincial health directorates provide technical backstopping and programme monitoring to district health systems and come directly under Ministry of Social Development of province. There is one health office in 77 districts which are under provincial health directorate. The health delivery outletsin the country include health posts (HPs), primary health care centres (PHCCs), district hospitals,zonal hospitals, sub-regional hospitals, regional hospitals, and central level hospitals. ${ }^{18}$ This paper aims to examine common health problems and prescribing practices before and after the earthquake.

\section{METHODS}

This descriptive retrospective study was conducted within seven randomly selected HPs located in the three most earthquake-affected districts of Bhaktapur (Nagarkot, Sudal, Jhaukhel, Bageshwari, Gundu, Sirutar and Lokanthali), Kathmandu \{Sankhu, Danchhi (Thali), Nayapati, Tokha Saraswati, Badbanjyang, Bhimdhunga and Chhaimale $\}$ and Dhading (Naubise, Bairini, Nalang, Mahadev Besi, Murlibhanjyang, Salbas and Khalte). The patient records (patient and medication details) per month from each HP were selected from the OPD register by systematic random sampling for three months prior and three months after the earthquake. Data extracted from the patient records included demographics, medications prescribed and diagnoses made. In total, 584 patient records were included in the preearthquake assessment and 654 medical records in the post-earthquake assessment.

Each patient record was analysed using WHO drug use indicators and national treatment guidelines. The key indicators included the average number of drugs per encounter, percentage of drugs prescribed by generic name, percentage of encounters with an antibiotic prescribed and percentage of drugs prescribed from essential medicines list. ${ }^{19}$ The analysis also included most frequently prescribed drugs by therapeutic categories, prescription of albendazole in cases with the single diagnosis of worm infestation and antibiotics for the single diagnosis of common cold. Data collected were reviewed and audited by another member of the team to ensure the accuracy and completeness. The data were entered into Epidata-3.1, transferred into Microsoft Excel and verified before being analysed 
Table 1. Top 10 health problem in districts

\begin{tabular}{|l|l|r|r|}
\hline SN & $\begin{array}{c}\text { Diagnosis/health } \\
\text { problem }\end{array}$ & $\begin{array}{c}\text { Pre \% } \\
(\mathrm{n}=584)\end{array}$ & $\begin{array}{c}\text { Post \% } \\
(\mathrm{n}=654)\end{array}$ \\
\hline 1 & Headache & 6.0 & 8.7 \\
\hline 2 & Diarrhoea & 5.1 & 7.8 \\
\hline 3 & Gastritis & 5.3 & 5.5 \\
\hline 4 & Common cold & 5.1 & 4.3 \\
\hline 5 & Fever & 4.8 & 4.3 \\
\hline 6 & Tonsillitis & 4.5 & 4.3 \\
\hline 7 & Asthma & 4.8 & 3.4 \\
\hline 8 & Upper Respiratory Tract & 4.2 & 3.4 \\
\hline 9 & Infection & & \\
\hline 10 & Allergy & 2.6 & 3.4 \\
\hline & Cough & 3.9 & 2.2 \\
\hline
\end{tabular}

using SPSS-21. Ethical approval for the study was obtained from Nepal Health Research Council (NHRC).

\section{RESULTS}

The key health problems included headache, diarrhoea, gastritis, common cold and fever (Table-1). Male patients represented 44.3 and $44.1 \%$ and females 55.7 and $55.9 \%$ of the total number of out-patients evaluated in the pre and post earthquake periods respectively.

The average number of drugs per encounter was more in the post-earthquake period than preearthquake period. The difference was not significant (Table - 2). There was a significant decrease in a number of encounters receiving antibiotics in the post-earthquake period $(\mathrm{p}=$ 0.001 ). On the other hand, there was an increase in a number of drugs prescribed by generic name in the post-earthquake period, which was not significant (Table 3 and 4). Similarly, a decrease in

Table 3. Encounters receiving antibiotics

\begin{tabular}{|l|r|r|r|}
\hline & \multicolumn{1}{l}{$\begin{array}{l}\text { Pre } \\
(\mathrm{n}=584)\end{array}$} & $\begin{array}{l}\text { Post } \\
(\mathrm{n}=654)\end{array}$ & Significance \\
\hline Bhaktapur & 85 & 68 & \\
\hline Dhading & 93 & 97 & \\
\hline Kathmandu & 77 & 75 & \\
\hline $\begin{array}{l}\text { Percentage of } \\
\text { encounters with an } \\
\begin{array}{l}\text { antibiotic } \\
\text { prescribed (\%) }\end{array}\end{array}$ & 43.7 & 36.7 & $<0.001$ \\
\hline
\end{tabular}

Table 2. Drugs prescribed by district

\begin{tabular}{|c|c|c|c|c|}
\hline District & $\begin{array}{l}\text { Bhaktap } \\
\text { ur } \\
\text { (number } \\
\text { of drugs } \\
\text { prescribe } \\
\text { d) }\end{array}$ & $\begin{array}{l}\text { Dhading } \\
\text { (number } \\
\text { of drugs } \\
\text { prescribe } \\
\text { d) }\end{array}$ & $\begin{array}{l}\text { Kathman } \\
\text { du } \\
\text { (number } \\
\text { of drugs } \\
\text { prescribe } \\
\text { d) }\end{array}$ & $\begin{array}{l}\text { Average } \\
\text { number } \\
\text { of drugs } \\
\text { per } \\
\text { encounte } \\
\text { r }\end{array}$ \\
\hline$(n=584)$ & 342 & 347 & 329 & 1.7 \\
\hline$(\mathrm{n}=654)$ & 439 & 393 & 358 & 1.8 \\
\hline $\begin{array}{l}\text { Significan } \\
\text { ce }\end{array}$ & & & & 0.986 \\
\hline
\end{tabular}

$N=$ number of encounters

a number of drugs prescribed from Essential Drugs List of Nepal was found in the post-earthquake period. The difference was also not significant (Table 4).

A significant decrease in cases receiving albendazole alone in the single diagnosis of worm infestation was found in the post-earthquake period ( $p=0.001$, Table 5). On the other hand, a significant increase in prescribing antibiotics in cases with a single diagnosis of common cold was found in the post-earthquake period $(\mathrm{p}=0.001$, Table 6). Antibiotics were the most commonly utilised drugs followed by analgesics, anti-allergics, vitamins and antacids (Table 7).

\section{DISCUSSION}

The common health problems in the pre and post earthquake period were similar but there were more cases of headache and diarrhoea in the postearthquake period. The significant decrease in antibiotics prescribing during the post-earthquake period could be due to several reasons including limited availability, rationing of available antibiotics and fear of bacterial resistance and

Table 4. Drugs prescribed by generic name and from Essential Drugs List

\begin{tabular}{|l|r|r|r|}
\hline & \multicolumn{1}{|c}{ Pre } & \multicolumn{1}{c}{$\begin{array}{c}\text { Post } \\
(\mathrm{n}=1018)\end{array}$} & Significance \\
\hline $\mathrm{n}=1190)$ & \\
\hline $\begin{array}{l}\text { Drugs } \\
\text { prescribed } \\
\text { by Generic } \\
\text { name (\%) }\end{array}$ & 46.2 & 53.8 & 0.998 \\
\hline $\begin{array}{l}\text { Percentage } \\
\text { of drugs } \\
\text { prescribed } \\
\text { from EDL } \\
(\%)\end{array}$ & 88.1 & 84.1 & 0.894 \\
\hline
\end{tabular}


Table 5. Worm infestation cases receiving albendazole

\begin{tabular}{|l|r|r|}
\hline \multicolumn{1}{|l|}{ Cases } & \multicolumn{1}{c|}{ Percentage } & Significance \\
\hline Pre $(n=18)$ & $88.9 \%$ & $<0.001$ \\
\hline Post $(n=17)$ & $82.3 \%$ & \\
\hline
\end{tabular}

consequences. The percentage of individuals receiving antibiotics for the diagnosis of common cold was significantly higher in the post-earthquake period suggesting inappropriate utilisation of antibiotics. Healthcare providers antibiotic prescription may have been influenced by the media which consistently warned about the impending epidemic following the earthquakes. ${ }^{7}$

Of the total number of medications prescribed in the post-earthquake period in Nepal, only $53.8 \%$ were generic compared to $95.1 \%$ during the 2003 post-earthquake period in Bam, Iran. ${ }^{16}$ There has been a decrease in the use of analgesics though there were more cases of headache in the postearthquake period, could be due to availability problem. More oral rehydration salt (ORS) were prescribed in districts which is consistent with increased incidence of diarrheal diseases in the post-earthquake period.

The absence of psychotherapeutic drugs including sedatives and hypnotics in our study contradicts findings from the Bam study whereby $27 \%$ percent of patients received central nervous system (CNS) medications post-earthquake. ${ }^{16}$ Psychiatric disorders such as anxiety, post-traumatic stress disorders, and depression are common among

Table 7. Top 10 therapeutic categories of prescribed

\begin{tabular}{|l|l|r|r|}
\hline \multicolumn{1}{|l|}{$\begin{array}{l}\text { Therapeutic } \\
\text { category }\end{array}$} & $\begin{array}{c}\text { Pre \% } \\
(\text { n = 584) }\end{array}$ & $\begin{array}{c}\text { Post \% } \\
(\text { n=654) }\end{array}$ \\
\hline 1 & Antibiotic & 43.7 & 36.7 \\
\hline 2 & Analgesic & 41.7 & 37.0 \\
\hline 3 & Anti-allergy & 17.0 & 16.8 \\
\hline 4 & Vitamin & 15.4 & 21.3 \\
\hline 5 & Antacid & 9.1 & 8.0 \\
\hline 6 & Bronchodilator & 7.4 & 5.8 \\
\hline 7 & Antiamoebic & 6.8 & 11.8 \\
\hline 8 & Oral Rehydration & 6.2 & 10.1 \\
\hline 9 & Salt (ORS) & & \\
\hline 10 & Antihelminthic & 5.5 & 4.4 \\
\hline
\end{tabular}

survivors following a disaster and the lack of CNS medication prescription within three months postearthquake in Nepal could suggest lack of screening and recognition of signs and symptoms

We note few key limitations of this study. Data collection was limited to the Ministry of Health $(\mathrm{MoH})$ operated OPD register in health posts (HPs) and did not capture medications prescribed by multiple medical relief teams within the same geographic region.

\section{CONCLUSIONS}

The results of this study showed that headache and diarrhoea were common health problems and antibiotics and analgesics were most prescribed medications. Antibiotic and anthelmintic prescription decreased significantly in three months after the earthquake. There is a need for improving mental health education to the health workers.

\section{ACKNOWLEDGEMENTS}

We are thankful to District Health Officers/District Public Health Officers of the study districts for their valuable support. We are also grateful to Ms. Anushree Acharya and Ms. Manita Shrestha, Research Assistants for their sincere work in collecting data. We would also like to thank Ms. Alisha Bhomi, Mr. Bibek Balla, Ms. Dina Pradhan, Ms. Dipta Amatya, Ms. Prabisha Amatya and Ms. Shanti Tamang from different organizations for their cooperation in the district. of such conditions. ${ }^{9}$ 
To cite this article: Bhuju GB, Kafle KK, Regmi D, Prasad RR, Rajbhandari V, D. C GB, et al. Pattern of Medicine Prescribing in PHC Facilities before and after earthquake in Nepal. MJSBH. 2021;20(1):97-102.

Conflict of Interest: None declared

\section{REFERENCES}

1. Data for Nepal, Low income | Data [Internet]. [cited 2016 Sep 26]. Available from: http://data. worldbank. org/? locations $=\mathrm{NP}-\mathrm{XM}$

2. Nepal Earthquake 2015 [Internet]. [cited 2016 Sep 26]. Available from: https://www.icimod.org/nepalearthquake-2015/

3. Snapshot [Internet]. [cited 2016 Sep 26]. Available from: http://data. unhcr. org/nepal/

4. Koirala J. Effects of 2015 Earthquake on Nepalese Economy. Available SSRN 2603212 [Internet]. 2015 [cited 2016 Sep 26]; Available from: http://papers. ssrn. com/sol3/papers. cfm?abstract_id=2603212 DOI: 10.2139/ssrn. $2603212<$ doi $>$

5. Bagchi S. Risk of infection after the Nepal earthquake. Lancet Infect Dis. 2015;15(7):770-1. DOI: https://doi.org/ 10.1016/S1473-3099(15)00103-6

6. Nayak N. Earthquake aftermath-myth or reality? Nepal J Epidemiol. 2015;5(2):465. DOI: 10.3126/nje.v5i2.12827

7. Marahatta SB. Control of the Outbreak of Disease Aftermath Earthquake: an Overview. Nepal J Epidemiol. 2015;5(2):468. DOI: 10.3126/nje.v5i2.12828

8. Aydan Ö, Ulusay R. A quick report on the 2015 Gorkha (Nepal) earthquake and its geo-engineering aspects. Accessed Online On [Internet]. 2015 [cited 2016 Sep 26];24. Available from: http://www. iaeg. info/wp-content/ uploads/QuickRepot_2015NepalEarthquake_Aydan_Ulusay_IAEG.pdf

9. Montazeri A, Baradaran H, Omidvari S, Azin SA, Ebadi M, Garmaroudi G, et al. Psychological distress among Bam earthquake survivors in Iran: a population-based study. BMC Public Health. 2005;5:4. DOI: $10.1186 / 1471-2458-5-4$

10. Ho M, Lim J, Tan M, Kok W, Zhang J, Tan M, et al. Humanitarian Assistance and Disaster Relief mission by a tripartite medical team led by the Singapore Armed Forces after the 2015 Nepal earthquake. Singapore Med J. 2016;57(8):426-31. DOI: 10.11622/smedj.2016132

11. Nelson EJ, Andrews JR, Maples S, Barry M, Clemens JD. Is a Cholera Outbreak Preventable in Post-earthquake Nepal? PLoS Negl Trop Dis. 2015;9(8):e0003961. DOI: 10.1371/journal.pntd.0003961

12. Coles JB, Zhuang J, Yates J. Case study in disaster relief: A descriptive analysis of agency partnerships in the aftermath of the January 12th, 2010 Haitian earthquake. Socioecon Plann Sci. 2012;46(1):67-77. DOI: 10.1016/ j.seps.2011.08.002

13. Sareen H, Shoaf KI. Impact of the 1994 Northridge earthquake on the utilization and difficulties associated with prescription medications and health aids. Prehospital Disaster Med. 2000;15(4):173-80. DOI: 10.1017/ S1049023X00025280

14. Beaglehole B, Bell C, Frampton C, Hamilton G, McKean A. The impact of the Canterbury earthquakes on prescribing for mental health. Aust N Z J Psychiatry. 2015;49(8):742-50. DOI: 10.1177/0004867415589794

15. Trifirò G, Italiano D, Alibrandi A, Sini G, Ferrajolo C, Capuano A, et al. Effects of L'Aquila earthquake on the prescribing pattern of antidepressant and antipsychotic drugs. Int J Clin Pharm. 2013;35(6):1053-62. DOI: $10.1007 /$ s11096-013-9822-8

16. Sepehri G, Meimandi M-S. Pattern of drug prescription and utilisation among Bam residents during the first six months after the 2003 Bam earthquake. Prehospital Disaster Med. 2006;21(6):396-402. DOI: https://doi.org/ $10.1017 / \mathrm{S} 1049023 \mathrm{X} 00004106$

17. Sepehri G, Haj-Akbari N, Sepehri E, Mohsen-Beigi M. The quality of prescription drug utilisation five years after the 2003 Bam earthquake. Int J Health Care Qual Assur. 2012;25(7):582-91. DOI: https://doi.org/ $10.1108 / 09526861211261181$

18. Ministry of Health, Department of Health Services. Annual Report, Nepal; 2017/18

19. World Health Organisation. How to Investigate Drug Use in Health Facilities: Selected Drug Use Indicators - EDM Research Series No. 007 [Internet]. [cited 2016 Dec 6]. Available from: http://apps. who. int/medicinedocs/en/d/ Js2289e/\#Js2289e. 